\title{
PENGEMBANGAN MEDIA PEMBELAJARAN MEMAHAMI CERITA FANTASI BERBASIS POWER POINT UNTUK SISWA SMP
}

\author{
Winda Devi Novitasari ${ }^{1}$, Sukiman $^{2}$, M. Zakia Firdaus ${ }^{3}$ \\ ${ }^{1,2,3}$ Pendidikan Bahasa Indonesia, Universitas Billfath
}

INFO ARTIKEL

Diterima: 1-7-2021

Disetujui: 3-9-2021

\section{Kata Kunci:}

Memahami; Cerita

fantasi; Powerpoint

\begin{abstract}
Abstrak:
Penelitian ini bertujuan untuk mengetahui pengembangan media pembelajaran berbasis power point dalam memahami cerita fantasi kelas VII; mengetahui hasil penilaian media komik berbasis power point; dan, mengetahui hasil tingkat kelayakan media komik berbasis power point. Metode yang digunakan dalam penelitian ini adalah metode R\&D yang terdapat 10 langkah, namun dalam penelitian ini hanya menggunakan 6 langkah. Data dikumpulkan dengan instrument penelitian berupa observasi, wawancara dan angket. Hasil penelitian diperoleh dari hasil validasi ahli dan respon peserta didik, berdasarkan data yang telah diperoleh dari validasi ahli dan pengisian angket respon oleh 18 orang subjek. Media yang diujikan telah diuji kelayakannya dengan tingkat presentase $90 \%$ dengan kategori sangat baik sehingga media dapat diterapkan di kelas.
\end{abstract}

\section{Abstract:}

The research aims for is acquainted with the development of power-based learning media in understanding the class VII fantasy story; for the power point media assessment; get the level of media worth of comics based on power point. The methods used in this research are methods abtract peini the $R \& D$ has 10 steps, but it uses only 6 in the study. Data collected with research instruments of observation, interview, and angket. Study result obtained from results of expert validator and protage responses, based on data that has been acquired from expert validation and response recharging by 18 people subject. The media which is praised has been tested at $90 \%$ rate of presentation so well that the media can applied in the class

\footnotetext{
Nama $\quad$ : Winda Devi Novitasari ${ }^{1}$, Sukiman $^{2}$, M. Zakia Firdaus ${ }^{3}$

Instansi : Universitas Billfath

Alamat instansi : Komplek PP Al-Fattah Siman, Sekaran, Lamongan

Surel : windadevi13@gmail.com ${ }^{1}$, ukitarano@gmail.com $^{2}$, mzakiafirdaus@gmail.com $^{3}$.
}

Menulis merupakan kegiatan mencatat suatu informasi penting atau kegiatan menciptakan suatu karya tertentu. Menulis menjadi kegiatan yang sering dilakukan setiap manusia dalam melaksanakan aktivitas sehari-hari, dengan menulis kita juga dapat menuangkan gagasan, perasaan, pikiran, dan ide-ide baru. Abbas (2006:159) juga menyatakan bahwa keterampilan menulis merupakan suatu keterampilan menuangkan pikiran, gagasan, pendapat, tentang sesuatu, tanggapan terhadap suatu pernyataan keinginan atau pengungkapan perasaan dengan menggunakan bahasa tulis. Kegiatan menulis merupakan bagian yang tidak terpisahkan dalam seluruh proses belajar mengajar. Menulis mempunyai banyak keuntungan salah satunya, dengan menulis kita dapat menggali kemampuan dan potensi diri. Melalui kegiatan menulis kita juga dapat mengembangkan berbagai gagasan Dalman (2018:3).

Kegiatan menulis dapat diungkapkan dalam bentuk karya sastra seperti puisi, prosa, cerpen atau salah satunya yang sering ditemui adalah mengarang cerita fantasi. Cerita fantasi merupakan cerita yang menampilkan tokoh, alur, latar, sudut pandang, dan tema yang derajat kebenaranya diragukan baik menyangkut seluruh maupun sebagian cerita Nurgiyanto (2012:295). Dalam menulis cerita fantasi diperlukan daya imajinasi yang cukup luas agar 
menjadi karangan cerita yang padu dan menarik. Maka, untuk membagun daya imajinasi yang luas diperlukan cara atau media yang menarik untuk disajikan dalam proses belajar mengajar. Terdapat empat langkah dalam menulis cerita fantasi, langkah-langkah tersebut dapat memberikan pedoman dan arahan kepada penulis. Langkah tersebut terdiri atas penemuan ide, kemudian dibuat menjadi sebuah alur cerita, dan dikembangkan menjadi cerita yang sempurna Kemendikbud (2017:73).

Media pembelajaran merupakan alat bantu yang berfungsi untuk menjelaskan sebagian dari keseluruhan program pembelajaran yang sulit dijelaskan secara verba. Materi pembelajaran akan lebih mudah dan jelas jika dalam pembelajaran menggunakan media pembelajaran Musfiqon (2012:28). Salah satu media yang dapat digunakan untuk melatih kemampuan memahami dan menulis cerita fantasi adalah dengan menyajikan media berbasis power point berupa komik dengan fiture-fiture gambar kartun yang menarik.

Sejalan dengan pendapat Sadiman (2007:7) yang menyatakan bahwa media pembelajaran merupakan suatu bentuk komunikasi baik berupa cetak maupun audio visual dan peralatan yang mampu dimanfaatkan untuk mendukung proses belajar mengajar dikelas. Hal ini sesuai dengan fungsi media pembelajaran yaitu sebagai penjelas pesan agar tidak terlalu verbalistis atau tau katanya tetapi tidak tau maksudnya. Selain itu, fungsi media pembelajaran juga sebagai pembawa informasi dari sumber (guru) menuju penerima (siswa) Daryanto (2012:8).

Menurut Sudjana dan Rivai (2017:3-4) ada beberapa jenis media pengajaran yang biasa digunakan dalam proses pengajaran. Pertama, media grafis seperti gambar, foto, grafik, bagan atau diagram, poster, kartun, komik, dan lain-lain. Media merupakan salah satu hal yang penting dalam proses pembelajaran, karena dalam penggunaanya media pembelajaran memiliki fungsi dan manfaat dalam membantu proses pembelajaran.

Berdasarkan hasil observasi yang dilakukan di SMP Nurul Fattah Dadapan di mana masih banyak peserta didik yang mengalami kesulitan memahami materi pembelajaran khususnya cerita fantasi. Hal ini disebabkan kurangnya minat belajar peserta didik dan kurangnya pemanfaatan media. Selain itu, penyampaian materi pembelajaran juga hanya disampaikan secara verba sehingga peserta didik cenderung bosan dan mengantuk. Dengan demikian peneliti ingin memberikan suatu media pembelajaran yang dianggap mampu membantu meningkatkan minat belajar dan motivasi belajar peserta didik dalam memahami cerita fantasi yakni dengan menggunakan media komik berbasis power point. Sudjana \& Rivai (2017:64) menyatakan bahwa komik adalah suatu bentuk kartu yang mengungkapkan karakter dan memerankan suatu cerita dalam urutan yang erat dihubungkan dengan bentuk gambar dan dirancang untuk memberikan hiburan kepada para pembaca.

Media komik berbasis power point merupakan media gambar animasi yang disajikan menggunakan power point. Microsof power point merupakan salah satu aplikasi yang paling banyak digunakan oleh orang-orang dalam mempresentasikan bahan ajar, laporan, karya tulis, dan materi pembelajaran Azhar (2017:193). Sejalan dengan pendapat Daryanto (2012:181) yang menjelaskan bahwa Microsoft Power Point adalah sebuah software yang dibuat dan dikembangkan oleh perusahaan, dan merupakan salah satu program berbasis multimedia. Media ini menarik digunakan karena kemampuannya pengolahan teks, warna, dan gambar serta animasi-animasi yang bisa diolah sendiri sesuai kreatifitas penggunanya.

Media komik berbasis power point ini dipilih peneliti sebab peneliti ingin mengembangkan, mengenalkan, dan menjelaskan kepada peserta didik bahwasanya media pembelajaran berbasis power point ini sangat menarik digunakan dalam memahami materi pembelajaran. Dilakukannya penelitian ini juga bertujuan untuk mengetahui bagaimana tingkat kelayakan media komik berbasis power point dalam memahami cerita fantasi siswa kelas VII SMP. Dengan adanya penelitian ini diharapkan dapat menambah pengetahuan bagi pengajar untuk menggunakan media pembelajaran sebagai prantara penyampaian materi.

\section{METODE}

Penelitian ini merupakan jenis penelitian pengembangan. Penelitian pengembangan atau biasa disebut Research and Development (R\&D) ini merupakan salah satu metode penelitian 
yang sering digunakan. Metode yang digunakan dalam penelitian ini merupakan metode pengembangan menurut Borg and Gall dalam Sugiyono (2010:289). Model pengembangan Borg and Gall merupakan model pengembangan yang sering digunakan oleh kalangan peneliti lainnya. Menurut langkah-langkah pengembangan produk, model penelitian dan pengembangan ini lebih rasional dan lebih lengkap dari pada model penggembangan lainnya.

Berdasarkan metode penelitian Research and Development (R\&D) dengan menggunakan model menurut Borg and Gall, terdapat sepuluh langkah dalam pelaksanaan metode yang digunakan, namun di sini peneliti menyederhanakan langkah tersebut menjadi enam langkah dalam penelitian yang akan dilakukan, yaitu: (1) analisis kebutuhan, (2) desain produk, (3) pengembangan desain produk, (4) validas ahli, (5) revisi produk, dan (6) uji coba lapangan Sugiyono (2010:290).

Penelitian yang dilakukan menggunakan teknik analisis data deskriptif kualitatif dan analisis kuantitatif. Data yang diperoleh melalui kegiatan uji coba diklasifikasikan menjadi dua, yaitu data kualitatif dan data kuantitatif. Data kualitatif berupa kritik dan saran yang dikemukakan ahli media I, ahli media II, dan peserta didik dengan tujuan untuk memperbaiki produk media pembelajaran berbasis power point ini. Sementara data kuantitatif diperoleh dari hasil perhitungan validasi ahli dan kuesioner peserta didik Sugiyono (2010:290).

\section{HASIL DAN PEMBAHASAN}

Produk yang dikembangkan dalam penelitian dan pengembangan ini adalah sebuah media pembelajaran untuk memahami cerita fantasi. Media pembelajaran tersebut berupa media pembelajaran komik yang mana berbasis power point untuk peserta didik kelas VII SMP. Prosedur penelitian pengembangan (research and development) yang digunakan merupakan adaptasi dari langkah-langkah penelitian dan pengembangan Borg and Gall.

\section{Analisis Data Hasil Validasi}

Analisis data pada penelitian dan pengembangan media pembelajaran ini dilakukan dengan cara mengonversikan data kuantitatif ke data kualitatif pada lembar evaluasi. Pengubahan jenis data tersebut untuk mengetahui kualitas setiap aspek yang telah dinilai. Pengubahan jenis data tersebut dilakukan dengan menggunakan skala likert dengan rentang skor 1-5. Rentang dimulai dari kategori sangat kurang sampai rentang kategori sangat baik. Berikut analisis data media pembelajaran komik berbasis power point

\section{Analisis Data Hasil Validasi Media I}

Berdasarkan uraian data hasil validasi sebelumnya, maka dapat dilihat kategori dari aspek yang dinilai. Adapun aspek yang dinilai oleh ahli media I adalah aspek tampilan dan aspek isi pembelajaran. Berikut adalah analisis dari data yang telah dipaparkan sebelumnya.

Tabel 1. Analisis Data Berdasarkan Validasi Ahli Media I

\begin{tabular}{ccccc}
\hline Tahap & No & Aspek yang Dinilai & Nilai Rata-rata & Kategori \\
\hline \multirow{2}{*}{1} & 1 & Tampilan Media & 3 & Cukup baik \\
\cline { 2 - 5 } & 2 & Isi Pembelajaran & 2,4 & Kurang baik \\
\hline \multirow{2}{*}{2} & Rata-rata & $\mathbf{2 , 7}$ & Cukup baik \\
\cline { 2 - 5 } & 1 & Tampilan Media & 4 & Baik \\
\hline \multirow{2}{*}{3} & Isi Pembelajaran & 3,6 & Baik \\
\cline { 2 - 5 } & 1 & Rata-rata & $\mathbf{3 , 8}$ & Baik \\
\hline & 2 & Tampilan Media & 4,7 & Sangat baik \\
\hline & Isi Pembelajaran & 4,5 & Sangat baik \\
\hline
\end{tabular}

Berdasarkan analisis data yang telah dipaparkan di atas terlihat bahwa validasi media pada tahap satu, diperoleh skor rata-rata 3 khususnya pada aspek tampilan media. Apabila diukur dengan skala likret maka tampilan media termasuk dalam kategori cukup baik. Sementara itu, validasi media pada aspek isi pembelajaran memperoleh skor rerata 2,4 dengan kategori kurang baik. Dengan adanya hal tersebut, perlu adanya perbaikan agar media benarbenar layak untuk digunakan di kelas. 
Kemudian setelah itu, dilakukan validasi tahap kedua, pada validasi tahap kedua ini diperoleh skor 4 pada aspek tampilan media dan 3,6 pada aspek isi media dengan kategori baik. Namun, media masih perlu adanya perbaikan karena dirasa kurang layak untuk digunakan di kelas. Kemudian, masuk pada validasi tahap ketiga atau yang terakhir. Pada validasi tahap ketiga ini aspek tampilan media memperoleh skor 4,7 dan aspek isi pembelajaran memeperoleh skor 4,5 dengan kategori sangat baik. Setelah dilakukan validasi tahap ketiga ini barulah media dapat dinyatakan layak untuk digunakan di kelas.

\section{Analisis Data Hasil Validasi Media II}

Berdasarkan uraian data hasil validasi sebelumnya, maka dapat dilihat kategori dari aspek yang dinilai. Adapun aspek yang dinilai oleh ahli media II adalah aspek isi dan aspek tampilan. Berikut adalah analisis dari data yang telah dipaparkan sebelumnya.

Tabel 2. Analisis Data Berdasarkan Validasi Ahli Media II.

\begin{tabular}{|c|c|c|c|}
\hline No & Aspek yang Dinilai & Nilai Rata-rata & Kategori \\
\hline 1 & Tampilan media & 4,1 & Baik \\
\hline 2 & Isi media & 4,5 & Sangat baik \\
\hline & Rata-rata & 4,3 & Sangat baik \\
\hline
\end{tabular}

Berdasarkan uraian data di atas validasi media II pada aspek isi memperoleh skor 4,1 dengan kategori baik, sementara pada aspek pengajaran memperoleh skor 4,5 dengan kategori sangat baik. Dengan jumlah skor yang sudah termasuk dalam kategori baik tersebut, media tidak perlu dilakukan perbaikan lagi karena media sudah dinyatakan layak digunakan dalam kegiatan belajar mengajar oleh ahli materi.

\section{Analisis Data Hasil Uji Coba Lapangan}

Berdasarkan uraian data hasil validasi sebelumnya. Maka dapat dilihat kategori dan aspek yang dinilai. Adapun aspek yang dinilai oleh peserta didik adalah aspek tampilan dan aspek isi. Aspek tampilan mencakup pemilihan warna, keselarasan tulisan, pemilihan animasi, dan penentuan tokoh. Berikut adalah analisis data hasil uji coba lapangan.

Tabel 3. Kategori Aspek Tampilan dan Isi Berdasarkan Uji Coba.

\begin{tabular}{|c|c|c|c|}
\hline No & Aspek yang Dinilai & Nilai Rata-rata & Kategori \\
\hline 1 & Tampilan Media & 4,1 & Baik \\
\hline 2 & Isi Media & 4,5 & Sangat baik \\
\hline & Rata-rata & 4,3 & Sangat baik \\
\hline
\end{tabular}

Berdasarkan uji coba lapangan di atas validasi pada aspek tampilan memperoleh skor 4,1 dengan kategori baik, sementara itu, pada aspek isi materi memperoleh skor 4,5 dengan kategori sangat baik. Dengan jumlah skor keseluruhan 4,3 yang termasuk dalam kategori sangat baik media sudah dikatakan layak untuk digunakan. Dalam artian media yang dikembangkan berhasil menarik perhatian dan meningkatkan minat belajar peserta didik.

Uji coba produk media pembelajaran komik berbasis power point yang dilakukan di lokasi SMP Nurul Fattah Dadapan dapat dikatakan berjalan dengan lancar. Uji coba dilakukan di kelas VII SMP dengan jumlah 18 peserta didik. Pelaksanaan uji coba dilakukan pada hari Kamis, 01 April 2021 jam ke-4 dan ke-5 di ruang kelas dengan fasilitas leptop dan LCD. Sebelum uji coba dilakukan peneliti memulai kelas dengan menjelaskan tujuan pembelajaran yang akan dilaksanakan. Setelah kelas dibuka, masing-masing peserta didik menyaksikan dengan seksama video pembelajaran komik berbasis power point yang telah dibuat dan divalidasi sebelumnya.

Mulanya beberapa peserta didik masih berbicara dan tidak memperhatikan apa yang peneliti jelaskan mengenai penggunaan komik, namun pada saat komik ditampilkan suasana kelas menjadi tenang dan seluruh peserta didik fokus mengamati media yang ditampilkan menggunakan LCD. Peserta didik diberikan waktu mengamati selama 30 menit. Setelah seluruh peserta didik selesai mengamati media, dilakukan pembahasan ulang materi pada komik secara bersama-sama. 
KARANGAN: Jurnal Kependidikan, Pembelajaran, dan Pengembangan, Vol 03 No 02, Bulan September, Tahun 2021 Hal 73-78

Kemudian setelah itu, peserta didik diminta untuk menjawab latihan soal yang berkaitan dengan materi yang telah disampaiakan sebelumnya. Tugas terakhir setelah peserta didik mengerjakan beberapa pertanyaan yang diberikan adalah mengisi angket tentang penilaian terhadap media pembelajaran komik berbasis power point. Berdasarkan latihan soal dan angket respon peserta didik yang diberikan diperoleh data dan dilakukan analisis data yang menghasilkan:

\section{[1]. Analisis Respon Peserta Didik}

Hasil respon peserta didik diukur berdasarkan data yang telah diperoleh dari pengisian angket respon oleh 18 orang subjek, diperoleh rata-rata 4,5 dengan persentase pencapaian $90 \%$ dengan kategori sangat baik yang artinya peserta didik menyukai penggunaan komik sebagai media pembelajaran.

\section{[2]. Analisis Hasil Belajar Peserta Didik}

Nilai hasil belajar peserta didik yang diperoleh dari pengerjaan kuesioner dengan lima butir soal yang diberikan terpisah dari komik berbasis power point ini selanjutnya akan dianalisis sesuai dengan Kriteria Ketuntasan Minimal (KKM) yang digunakan di SMP Nurul Fattah Dadapan yakni 75. Sementara hasil yang diperoleh seluruh peserta didik mendapatkan nilai di atas KKM atau lebih dari 75. Secara keseluruhan persentase ketuntasan nilai hasil belajar 18 orang subjek tersebut adalah $100 \%$ dengan kategori sangat baik.

Sebelum proses belajar mengajar ditutup, peneliti yang juga bertindak sebagai guru menanyakan kepada peserta didik mengenai pembelajaran yang telah dilaksanakan. Berdasarkan jawaban peserta didik sebelum pelajaran ditutup proses belajar mengajar berlangsung lebih menarik karena adanya media pembelajaran komik berbasis power point dan proses belajar yang lebih santai namun tetap terkondisikan.

Peneliti juga menanyakan kesulitan selama pelaksanaan pembelajaran kepada peserta didik. Jawaban sebagian besar peserta didik tidak ditemukannya kesulitan pada media pembelajaran maupun pada saat memahami materi yang diberikan. Secara umum, berdasarkan tanggapan ahli media, guru, dan siswa, media pembelajaran komik berbasis power point ini mendapat tanggapan positif, komentar, dan saran yang membangun agar media lebih baik.

Pada penelitian dan pengembangan media pembelajaran menulis puisi ini hanya dilakukan uji coba untuk melihat kelayakan media pembelajaran yang dikembangkan. Pada penelitian ini, media pembelajaran tidak diukur kefektifannya. Untuk mengukur kefektifan media pembelajaran ini harus dilakukan penelitian lagi agar lebih jelas apakah media pembelajaran ini benar-benar efektif digunakan di dalam proses belajar mengajar di kelas.

\section{SIMPULAN}

Penelitian dan pengembangan media pembelajaran yang berjudul pengembangan media pembelajaran komik berbasisi power point dalam memahami cerita fantasi kelas VII SMP Nurul Fattah Dadapan ini menggunakan model pengembangan produk yang merujuk pada teori milik Borg and Gall yang sudah diadaptasi oleh peneliti sesuai dengan kebutuhan dan kondisi obyek dan subjek penelitian.

Penelitian ini berhasil mengembangkan media pembelajaran komik berbasis power point dengan baik. Media komik berbasisi power point dibuat berdasarkan kebutuhan guru dan peserta didik. Komponen dalam penyusunan media pembelajaran komik berbasis power point ini terdiri dari beberapa slide yakni, sampul, penyampaian indikator dan tujuan, pengenalan tokoh, pengenalan materi, barulah masuk pada penyampaian materi, dan penutup serta dipaparkan juga profil pengembang.

Media komik berbasis power point ini dinyatakan layak setelah melewati beberapa tahapan yaitu, tahap validasi ahli media I, tahap validasi ahli media II, dan uji coba lapangan. Presentase kelayakan media adalah 90\% dengan rata-rata 4,5 yang berkategori sangat baik. Berdasarkan kesimpulan tersebut, maka produk media pembelajaran komik berbasis power point dalam memahami cerita fantasi kelas VII ini dinyatakan sangat layak dan sangat membantu untuk digunakan dalam kegiatan belajar mengajar di kelas. 
KARANGAN: Jurnal Kependidikan, Pembelajaran, dan Pengembangan, Vol 03 No 02, Bulan September, Tahun 2021 Hal 73-78

\section{DAFTAR RUJUKAN}

Abbas, Saleh. 2006. Pembelajaran Bahasa Indonesia yang Efektif di Sekolah Dasar. Jakarta:Departemen Pendidikan Nasional Direktorat Jendral Pendidikan Tinggi Direktorat Ketenagaan.

Arsyad, Azhar. 2017. Media Pembelajaran. Jakarta:Rajawali Pers.

Dalman. 2018. Keterampilan Menulis. Depok:Rajawali Pers.

Daryanto. 2010. Media Pembelajaran. Bandung:Satu Nusa.

Kemendikbud. 2017. Pembelajaran Cerita Fantasi. Jakarta:Kementrian Pendidikan dan Kebudayaan.

Musfiqon. 2012. Pengembangan Media dan Sumber Pembelajaran. Jakarta:PT Prestasi Pustaka.

Nurgiyanto, B. 2012. Teori Pengkajian Fiksi. Yogyakarta: Gajah Mada University Press.

Sadiman, dkk. 2007. Media Pendidikan, Pengertian, Pengembangan, dan Pemanfaatannya. Jakarta: Rajawali Press.

Sudjana Nana, Rivai Ahmad. 2010. Media Pengajaran. Bandung: Sinar Baru Algensindo.

Sugiyono. 2010. Metode Penelitian Kuantitatif, Kualitatif, dan R\&D. Bandung: Alfabeta. 